\title{
HUBUNGAN ANTARA KESEGARAN JASMANI, DISIPLIN DAN PERCAYA DIRI TARUNA DENGAN PRESTASI AKADEMIK TARUNA SEKOLAH TINGGI TRANSPORTASI DARAT BEKASI JAWA BARAT
}

\author{
Santoso ${ }^{1}$, Achmad Sofyan Hanif, Johansyah Lubis \\ ${ }^{1}$ Universitas Negeri Jakarta
}

\begin{abstract}
Abstrak
Tujuan dari penelitian ini adalah untuk mempelajari antara Kesegaran Jasmani, disiplin, dan percaya diri dengan prestasi akademik penelitian ini dilakukan di Sekolah Tinggi Transportasi Darat di Bekasi Jawa barat, dengan $n=118$ taruna dipilih secara acak. Data dianalisis menggunakan korelasi sederhana, beberapa korelasi, regresi sederhana dan regresi berganda. Hasil analisis data menggunakan teknik korelasi Product Moment pada hubungan antara kesegaran jasmani dengan prestasi akademik, dengan koefisen korelasi sebesar 0,641. Hasil pengujian diperoleh thitung $(8,99)$ lebih besar dari tabel $(2,62)$ pada $\alpha=$ 0,01. Data analisis pada hubungan antara disiplin dengan prestasi akademik, dengan koefisien korelasi sebesar 0,631 . Hasil pengujian diperoleh thitung $(8,76)>\operatorname{tabel}(2,62)$ pada $\alpha=0,01$. Data analisis pada hubungan antara percaya diri dengan prestasi akademik dengan koefisien korelasi sebesar 0,622. Hasil pengujian diperoleh thitung $(8,56)>$ tabel $(2,62)$ pada $\alpha=0,01$. Dan data analisis hubungan antara kesegaran jasmani, disiplin dan percaya diri secara bersama-sama dengan prestasi akademik dengan koefisien korelasi sebesar 0,814. Hasil uji signifikannya diperoleh Fhitung $(74,61)>$ Ftabel $(3,96)$ pada $\alpha=0,01$. Penelitian ini menyimpulkan bahwa ada korelasi positif antara: (1) Kesegaran Jasmani dan prestasi akademik, (2) disiplin dan prestasi akademik, (3) percaya diri dan prestasi akademik, dan (4) Kesegaran jasmani, disiplin, dan percaya diri secara bersama-sama dengan prestasi akademik. Oleh karena itu, prestasi akademik dapat di tingkatkan dengan meningkatkan Kesegaran Jasmani, disiplin, dan percaya diri
\end{abstract}

Keywords: hubungan, kesegaran jasmani, disiplin, percaya diri, prestasi akademik

\section{PENDAHULUAN}

Kegiatan pembelajaran yang dilakukan oleh taruna STTD yang dilakukan selama tiga dan empat tahun mempunyai tolok ukur akademik yang di nilai setiap semesternya. Nilai inilah yang menjadi salah satu acuan pokok di samping kepribadian dan kesegaran jasmaninya. Di sekolah yang memakai system 'boarding School', Semua kegiatan dari awal pembelajaran sampai kembali istirahat diberikan rambu-rambu yang harus di ikuti oleh seluruh sivitas yang sedang mejalani pendidikan. Dalam penyebutan mahasiswa pun juga berbeda. Untuk civitas yang sedang menjalani pendidikan di Sekolah Tinggi trasnportasi Darat disebut sebagai
"Taruna". Di dalam perkembangannya nilai akademik atau Prestasi akademik tersebut dapat dicapai apabila taruna dapat menyelesaikan proses pembelajaran yang telah ditetapkan dan di dalam pelaksaanannya banyak sekali unsur yang dapat mempengaruhi prestasi akademik.

Prestasi akademik menjadi salah satu nilai mutlak yang harus di tempuh di Sekolah tinggi Transportasi Darat maka penulis tertarik untuk meneliti hal hal yang berkaitan atau di duga berkaitan langsung maupun tidak langsung terhadap Prestasi Akademik ini.

Sekolah Tinggi Transportasi Darat memberikan peraturan yang berkaitan langsung dengan keseharian seorang 
taruna yaitu kesehatan dan mental taruna. Di sekolah yang menganut system di asramakan tidak lepas dari peraturan-peraturan yang di buat untuk kelangsungan proses pembelajaran di Sekolah. Dengan niat yang di miliki dia wal proses pembelajaran adalah salah satu yang dapat mempengaruhi keberlangsungan seorang taruna dalam menjalankan proses pembelajaran sampai selesai.

Kegiatan keseharian yang dilaksanakan di STTD salah satunya adalah Olahraga. Kegiatan olahraga yang dipandang oleh pemerintah Indonesia sendiri menjadikan terwujudnya manusia yang sehat dan menempatkan olahraga sebagai salah satu arah kebijakan untuk meningkatkan kualitas manusia yang memiliki tingkat kesehatan dan kesegaran jasmani yang cukup. Hal tersebut pula yang terus dilakukan secara berkelanjutan di sekolah-sekolah kedinasan.

Salah satu kegiatan yang harus di ikuti oleh setiap taruna di Sekolah Tinggi Transportasi Darat adalah pelajaran untuk menjaga kesehatan dan kesegaran jasmani, dalam hal ini sesuai dengan tujuan pendidikan jasmani yaitu untuk mengembangkan aspek kebugaran jasmani, keterampilan gerak, keterampilan berfikir kritis, keterampilan penalaran, stabilitas emosional, tindakan moral dan aspek pola hidup sehat.

Taruna dalam kesehariannya pula, di tuntut untuk bisa mengembangkan diri dengan sistem yang ada. Kedisiplinan merupan faktor penting dalam menjalankan seluruh kegiatan yang sudah terprogram dari Sekolah Tinggi Transportasi Darat. Pembatasan pembatasan yang dibuat untuk menjamin setiap taruna dapat mengikuti pebelajaran dengan baik, tertib, aman dan nyaman. Dalam mengikuti kegiatan mulai dari bangun tidur sampai tidur kembali semuanya dilakukan di lingkungan Sekolah Tinggi Transportasi Darat.

Taruna juga di tuntut untuk prima, dalam hal ini proses pembelajaran pendidikan jasmani sangat berperan penting. Keharusan taruna untuk selalu sehat dan bugar merupakan salah satu kunci untuk tetap bisa menjalankan seluruh aktivitas kegiatan di dalam kampus. Olahraga rutin sesuai jadwal secara langsung dan bersama-sama sesuai dengan tingkatan taruna. Proses pembelajaran secara langsung tersebut yang diharapkan menjadikan seluruh taruna tetap prima dalam menjalankan tugas keseharian. Dalam hal ini bisa terlihat pada saat tes kesegaran jasmani taruna yang dilakukan 6 bulan sekali.

Disiplin menjadi salah satu karakter yang harus ditanamkan dalam sitem pembelajaran untuk menjadikan kampus yang kondusif, maka dibuatlah peraturan-peraturan yang harus di jalankan taruna agar pada saat setelah selesai seluruh proses pendidikan, taruna bisa menjadi manusia yang berdisiplin dan beretika.

Untuk dapat menyelesaiakan tugas keseharian maupun ujian, kepribadian taruna haruslah muncul dari kesadaran diri sendiri. Percaya diri menjadi salah satu hal yang terlihat dari seorang taruna dalam menjalankan tugas maupun ujian. Dengan hal tersebut peneliti tertarik untuk mengungkapkan salah satu faktor kepribadian yaitu percaya diri kedalam hal yang berhubungan dengan prestasi akademik. Dengan percaya diri yang kuat dan cukup di harapkan seorang taruna dapat menunaikan tugas belajarnya dengan baik.

Kesegaran jasmani yang digunakan di sekolah tinggi transportasi 
darat mengacu kepada kesesuaian pada kegunaan kehidupan keseharian taruna yang padat. Dan kondisi tubuh taruna yang tetap segar dan bugar untuk melakukan kegiatan tanpa mengalami kelelahan yang berarti. Yang di kesegaran jasmani maksud disini adalah control terhadap daya tahan jantung paru dan daya tahan otot.

Maksud disiplin disini ialah ketaatan dan kesadaran diri dalam menjalankan seluruh peraturan. Dalam hal ini aspek disiplin yaitu: 1) Ketaatan, 2) Kesetiaan, dan 3) Kepatuhan dan 4) Ketertiban.

Untuk percaya diri disini disesuikan dengan dimensi yang sudah ada dan sesuai dengan yang akan dicapai di dalam proses pembelajaran di Sekolah Tinggi Transportasi Darat. Dimensi itu antara lain: self concept, self esteem, self afficacy dan self confidence beserta indikator yang menyertainya.

Penilaian Prestasi akademik disini ialah hasil belajar di Sekolah Tinggi Transportasi Darat yang telah diikuti oleh seluruh taruna yaitu nilai semester atau nilai Indeks Prestasi Komulatif Semester.

Prestasi merupakan hasil dari suatu kegiatan yang telah dikerjakan, diciptakan, baik secara individual maupun kelompok. Prestasi tidak akan pernah dihasilkan tanpa suatu usaha baik berupa pengetahuan maupun berupa keterampilan. Prestasi menyatakan hasil yang telah dicapai, dilakukan, dikerjakan dan sebagainya, dengan hasil yang menyenangkan hati dan diperoleh dengan jalan keuletan kerja.

Menurut Syaiful Bahri Djamarah, Prestasi Belajar adalah hasil yang diperoleh berupa kesan-kesan yang mengakibatkan perubahan pada diri individu sebagai hasil dari aktivitas dalam belajar. Perubahan yang dimaksud ialah segala bentuk perubahan yang terjadi di diri orang yang sudah melakukan suatu proses pembelajaran. Nilai akhir atau hasil evaluasi menjadi salah satu tolok ukur dalam perubahanperubahan individu yang dimaksud. Hal ini sejalan dengan definisi belajar yaitu memperlihatkan perubahan dalam perilaku sebagai hasil dari pengalaman".

Perwujudan secara nyata yang tampak dari prestasi akademik adalah adanya hasil penilaian atau hasil evalusi yang dapat di ketahui oleh seluruh taruna dari proses pembelajaran yang di jalaninya karena prestasi akademik merupakan suatu keberhasilan yang khusus dari taruna dalam melaksanakan tugas akademik.

Prestasi akademik juga tidak terlepas dari keberhasilan proses belajar seseorang Terdapat 2 (dua) faktor yang dapat mempengaruhi keberhasilan belajar seseorang yaitu: Faktor internal dan faktor eksternal.

Beberapa faktor internal yang mempengaruhi prestasi akademik diantarannya adalah "faktor Kesehatan Fisik, Intelegensi, Motivasi, minat, kepribadian dan fisiologis". Seseorang yang mengalami kelemahan fisik baik karena sakit maupun cacat di mana saraf sensoris dan motoriknya terganggu dapat mengakibatkan rangsangan yang diterima melalui indera tidak dapat diteruskan ke otak dengan baik. Kondisi ini dapat menyebabkan taruna tertinggal dalam pelajarannya. Intelegensi seseorang mempengaruhi potensi orang tersebut untuk menyelesaikan pendidikannya dan potensi itu sesuai dengan tingkatan kemampuan berfikir yang dimilikinya, semakin tinggi intelegensi seseorang maka semakin baik pula potensinya. Dengan melalui ujian saringan masuk perguruan tinggi yang demikian ketat persaingannya 
secara praktis sebenarnya Taruna sudah terseleksi dalam hal aspek intelegensinya. Namun kenyataan menunjukkan masih cukup besar kendala bagi Taruna untuk mendapatkan prestasi yang baik. Intelegensi bukan satu-satunya yang menentukan prestasi akademik Taruna.

Motivasi merupakan sesuatu yang mengarahkan dan membangkitkan suatu tingkah laku pada manusia baik dari diri sendiri yakni berupa kebutuhankebutuhan tertentu seperti kebutuhan fisiologis, rasa aman, rasa cinta, penghargaan maupun dari orang lain. Setiap Taruna memiliki motivasi yang berbeda-beda untuk berprestasi.

Faktor yang lain yang disebutkan yaitu minat, merupakan rasa suka dan ketertarikan terhadap sesuatu yang muncul dari dalam diri sendiri tanpa ada yang menyuruh. Minat tidak dibawa sejak lahir melainkan diperoleh kemudian melalui proses pembelajaran terhadap hal yang diminati. Minat yang besar terhadap sesuatu merupakan modal yang besar dalam mencapai ataupun memperoleh benda atau tujuan yang diinginkan.

Timbulnya minat belajar disebabkan oleh berbagai hal, antara lain karena keinginan yang kuat untuk menaikan martabat atau memperoleh pekerjaan yang baik serta ingin hidup senang dan bahagia. Minat belajar yang besar cenderung menghasilkan prestasi yang tinggi, sebaliknya minat yang kurang akan menghasilkan prestasi yang rendah.

Pribadi yang seimbang sangat mempengaruhi proses belajar, pribadi yang seimbang dapat menciptakan kesehatan mental dan ketenangan emosi yang dapat mendorong keberhasilan dalam belajar Tiap-tiap orang mempunyai sifat kepribadiannya masing-masing yang berbeda dengan orang lain. Ada orang memiliki sikap keras hati, berkemauan keras, tekun dalam segala usahanya, halus perasaannya dan sebaliknya. Sifat- sifat kepribadiannya dapat mempengaruhi sampai manakah hasil belajar yang dapat dicapai oleh orang tesebut.

Kondisi fisiologis pada umumnya sangat berpegaruh terhadap kemampuan belajar seseorang. Orang yang dalam keadaan segar jasmaninya akan lain cara belajarnya dari orang yang dalam keadaan kelelahan. Anak-anak yang kekurangan gizi memiliki kemampuan belajar yang di bawah anak-anak yang tidak kekurangan gizi. Mereka lekas lelah, mudah mengantuk, dan sukar menerima pelajaran.

Kurikulum merupakan unsur substansial dalam pendidikan. Tanpa kurikulum kegiatan belajar mengajar tidak dapat berlangsung, sebab materi apa yang harus guru sampaikan dalam suatu pertemuan kelas belum guru programkan sebelumnya. Itulah sebabnya, untuk semua mata pelajaran, setiap guru memiliki kurikulum untuk mata pelajaran yang dipegang dan diajarkan kepada anak didik. Setiap guru harus mempelajari dan menjabarkan isi kurikulum ke program yang lebih rincidan jelas sasarannya, sehingga dapat diketahui dan diukur dengan pasti tingkat keberhasilan belajar mengajar yang telah dilaksanankan.

Muatan kurikulum akan mempengaruhi akan mempengaruhi intensitas dan frekuensi belajar anak didik. Seorang guru terpaksa menjejalkan sejumlah bahan pelajaran kepada anak didik dalam waktu yang masih sedikit tersisa, karena ingin mencapai target kurikulum, akan memaksa anak didik belajar dengan keras tanpa mengenal lelah. Padahal 
anak didik sudah lelah belajar ketika itu. Tentu saja hasil belajar yang demikian kurang memuaskan dan cenderung mengecewakan.

Berdasarkan dari faktor yang mempengaruhi prestasi akademik, penelitian ini memfokuskan diri terhadap hal - hal yang yang dilakukan oleh taruna Sekolah Tinggi Transportasi Darat yang berhubungan dengan Prestasi Akademik Taruna.

Kesanggupan seseorang untuk menjalankan hidup produktif dan dapat menyesuaikan diri pada tiap pembebanan fisik yang layak adalah pengertian lain dari kesegaran jasmani. Kondisi jasmani yang menggambarkan potensi kemampuan jasmani untuk melakukan tugas-tugas tertentu dengan hasil yang opimal tanpa memperlihatkan keletihan yang berarti. Kehidupan keseharian di dalam lingkungan kampus yang diasramakan memerlukan kesegaran jasmani yang cukup.

Kesegaran Jasmani adalah kemampuan seseorang untuk menunaikan tugasnya sehari-hari dengan gampang, tanpa merasa lelah yang berlebihan, serta masih mempunyai sisa atau cadangan tenaga untuk menikmati waktu senggangnya dan untuk keperluan-keperluan mendadak. dengan kata lain Kesegaran jasmani dapat pula didefinisikan sebagai kemampuan untuk menunaikan tugas dengan baik walaupun dalam keadaan sukar, dimana orang yang kesegaran jasmaninya kurang, tidak akan dapat melakukannya. Hasil dari proses pembelajaran yang telah dicapai dapat mengungkapkan keterserapan proses pembelajaran yang telah dilakukan.

Kehidupan sehari-hari taruna tidak lepas dari aktivitas atau kegiatan, kadang kegiatan itu taruna lakukan dengan tepat waktu tapi kadang juga tidak. Kegiatan yang taruna laksanakan secara tepat waktu dan dilaksanakan secara berkelanjutan, maka akan menimbulkan suatu kebiasaan. kebiasaan dalam melaksanakan kegiatan secara teratur dan tepat waktulah yang biasanya disebut disiplin dalam kehidupan sehari-hari. disiplin diperlukan dimanapun, karena dengan disiplin akan kehidupan yang teratur dan tertata.

Pengertian disiplin dari beberapa ahli. Disiplin adalah sikap mentaati peraturan dan ketentuan yang telah ditetapkan tanpa pamrih. Suatu kondisi yang tercipta dan berbentuk melalui proses dari serangkaian perilaku yang menunjukan nilai-nilai ketaatan, kepatuhan, kesetiaan, keteraturan dan keterikatan. Disiplin sebagai upaya mengendalikan diri dan sikap mental individu atau masyarakat dalam mengembangkan kepatuhan dan ketaatan terhadap peraturan dan tata tertib berdasarkan dorongan dan kesadaran yang muncul dari dalam hatinya.

Disiplin biasanya diartikan sebagai perilaku dan tata tertib yang sesuai dengan peraturan dan ketetapan, atau perilaku yang diperoleh dari pelatihan, seperti disiplin dalam kelas atau disiplin dalam tim bola basket yang baik.

Sedangkan kata mendisiplin didefinisikan sebagai menciptakan keadaan tertib dan patuh dengan pelatihan dan pengawasan dan menghukum atau mengenakan denda, membetulkan, menghukum demi kebiasaan.

Disiplin merupakan perilaku seorang taruna yang sesuai dengan tata tertib atau aturan yang berlaku baik yang muncul dari kesadaran dirinya maupun karena adanya sanksi atau hukuman. Maka yang dimaksud disiplin dalam 
penelitian ini adalah sikap atau tingkahlaku taruna yang taat dan patuh untuk dapat menjalankan kewajibannya untuk belajar, baik belajar di sekolah maupun belajar di rumah. Indikator disiplin belajar dalam penelitian ini adalah: ketaatan terhadap tata tertib sekolah, ketaatan terhadap kegiatan belajar di sekolah, ketaatan dalam mengerjakan tugas-tugas pelajaran, dan ketaatan terhadap kegiatan belajar di rumah.

Disiplin diperlukan oleh siapapun dan di manapun, begitupun seorang taruna dia harus disiplin baik itu disiplin dalam menaati tata tertib sekolah, disiplin dalam belajar di sekolah, disiplin dalam mengerjakan tugas, maupun disiplin dalam belajar di rumah, sehingga akan dicapai hasil belajar yang optimal. Disiplin berperan penting dalam membentuk individu yang berciri keunggulan. Disiplin penting karena alasan diantaranya, Dengan disiplin yang muncul karena kesadaran diri, taruna berhasil dalam belajarnya. Sebaliknya taruna yang kerap kali melanggar ketentuan sekolah pada umumnya terhambat optimalisasi potensi dan prestasinya. Tanpa disiplin yang baik, suasana sekolah dan juga kelas menjadi kurang kondusif bagi kegiatan pembelajaran.

James Tangkudung menyebutkan bahwa Pada dasarnya manusia mempunyai kepribadian yang berbeda antara satu dengan yang lainnya. Kepribadian adalah suatu sifat yang hakiki yang dimiliki oleh seseorang yang tercermin di dalam sikapnya atau perbuatan yang berbeda dengan pribadipribadi lainya. Di dalam kepribadian terdapat percaya diri yang di miliki oleh setiap taruna. Banyak faktor yang mempengaruhi prestasi akademik. Di dalam kepribadian menjadi salah satu yang mempengaruhi prestasi akademik, yang di dalamnya terdapat percaya diri. Di dalam keseharian percaya diri menjadi salah satu yang dapat mempengaruhi keberlangsungan seorang taruna untuk tetap terus menjalankan proses pembelajarannya dengan baik. Sebab dengan tidak adanya percaya diri dapat menimbulkan keraguraguan dalam menjalankan kegiatan belajar di keseharian.

Harapan yang realistis mengenai kemampuannya untuk mencapai keberhasilan menjadi salah satu keyakinan akan harapan-harapan khusus dari kegiatan yang telah dilakukan oleh taruna untuk dapat memperoleh suatu keberhasilan dalam proses pembelajaran.

Hal ini sejalan dengan penjelasan mengenai percaya diri oleh Monti yaitu self-confidence berhubungan erat dengan pemenuhan diri (self-fullfiling prospeshy) dan keyakinan diri (selfeficacy). Penjelasan di atas dapat juga diperkuat bahwa dengan keyakinan dan kemampuan diri sendiri yang tidak terpengaruh oleh orang lain akan mampu mengetahui seluruh keputusan yang telah diambil untuk menjadi seorang taruna dan dalam melaksanakan kegiatan sehari-hari akan dapat dilalui dan sesuai dengan apa yang diharapkan dan diinginkan.

Mengungkapkan bahwa percaya diri dapat menyebabkan taruna memperoleh kegembiraan atau ketakutan. Kegembiraan bisa diartikan sebagai pengalaman emosional yang ditampilkan pada saat semua kegiatan telah dijalankan sesuai dengan yang di inginkan. Dalam hal ini tidak terlepas dari hasil prestasi akademik yang di nilai setiap periode waktu yang telah dijalankan. 
Percaya diri akan menimbulkan rasa aman dan akan terlihat dari tingkah laku taruna yang tampak tenang, tidak mudah bimbang atau ragu- ragu dan tegas. Hal ini dengan sendirinya akan menimbulkan kesadaran untuk melakukan sesuatu tanpa harus diperintah oleh orang lain. Hal tersebut sejalan dengan percaya diri yang disampaikan oleh Sudibyo yang menjelaskan bahwa percaya diri erat hubungannya dengan emotional Security.

Pemberian rasa aman dan keyakinan diri untuk tetap menjalankan kegiatan yang di lakukan di sekolah tinggi Transportasi Darat menjadi salah satu jaminan untuk semua taruna dapat menyelesaikan proses pembelajaran tepat waktu sesuai dengan jadwal yang telah dibuat.

Percaya diri dapat memberikan dampak positif kepada taruna karena dalam keadaan tertekan, taruna akan dapat menguasai dirinya untuk bertindak lebih tenang dan dapat menentukan saat yang tepat untuk melakukan suatu tindakan. Taruna juga dapat memusatkan perhatiannya pada hal-hal yang mengkhawatirkan atau waspada terhadap hal-hal yang mendadak. Kecenderungan taruna untuk berupaya lebih baik sehingga dalam mencapai suatu target akan lebih mudah.

\section{METODE}

Penelitian ini bertujuan memperoleh jawaban yang akurat tentang hubungan antara Kesegaran Jasmani, Disiplin dan Percaya Diri taruna dengan Prestasi Akademik taruna Sekolah Tinggi Transportasi Darat, baik yang dilakukan secara bersama-sama maupun dengan sendiri-sendiri. Secara operasional tujuan penelitian adalah untuk menjawab pertanyaan sebagai berikut:
1. Terdapat hubungan antara Kesegaran Jasmani Taruna (X1) dengan Prestasi Akademik Taruna (Y) Sekolah Tinggi Transportasi Darat Bekasi Jawa Barat. 2. Terdapat hubungan antara Disiplin Taruna (X2) dengan Prestasi Akademik Taruna (Y) Sekolah Tinggi Transportasi Darat Bekasi Jawa Barat. 3. Terdapat hubungan antara Percaya Diri Taruna (X3) dengan Prestasi Akademik Taruna (Y) Sekolah Tinggi Transportasi Darat Bekasi Jawa Barat. 4. Terdapat hubungan antara Kesegaran Jasmani (X1), Disiplin (X2) dan Percaya Diri (X3) Taruna secara bersama-sama dengan Prestasi Akademik taruna (Y) Sekolah Tinggi Transportasi Darat Bekasi Jawa Barat.

Metode yang dipakai dalam penelitian ini adalah metode survey karena peneliti tidak memberikan perlakuan hanya mengambil data di lapangan. Adapun teknik statistik yang dipergunakan adalah analisis korelasional yaitu menghubungkan dua variabel antara variabel bebas dengan variabel terikat, sehingga dalam penelitian ini tidak ada pengendalian terhadap perlakuan juga tidak ada ubahan penelitian.

Dalam penelitian ini terdapat dua macam variabel, yaitu variabel terikat dengan variabel bebas, variabel terikat Prestasi Akademik (Y) sedangkan variabel bebas terdapat tiga variabel yaitu Kesegaran Jasmani (X1), Disiplin (X2) dan Percaya Diri (X3).

Penelitian ini dilaksanakan di Sekolah Tinggi Transportasi Darat.Waktu Penelitian dari mulai uji coba instrumen sampai dengan pengolahan data dilakukan mulai bulan Mei 2016 sampai dengan Agustus 2016.

Populasi dalam penelitian ini adalah taruna taruna di Sekolah Tinggi Transportasi Darat Bekasi, Jawa Barat. 
Sampel dalam penelitian adalah sebagian dari populasi. Teknik pengambilan sampel yang digunakan adalah Random Sampling, yaitu cara penarikan sampel yang dilakukan secara acak sederhana. Populasi target yang terjangkau Sekolah Tinggi Transportasi Darat Bekasi, Jawa Barat yang

berjumlah 169 Taruna.

Instrument yang digunakan dalam penelitian ini adalah satu Instrument variabel terikat yaitu Prestasi Akademik (Indeks Prestasi Kumulatif) dan tiga instrument variabel bebas yaitu Tes Kesegaran Jasmani (Tes Kesegaran Jasmani Taruna STTD), Disiplin (Quesioner) dan Percaya Diri (Quesioner).

\section{HASIL DAN PEMBAHASAN}

Setelah melalui proses pengumpulan data, selanjutnya dilakukan analisis data meliputi: (1) deskripsi data untuk masing-masing variabel; (2) pengujian persyaratan analisis, yang berupa uji normalitas galat taksiran regresi dan uji signifikasi serta uji linearitas regresi; (3) pengujian hipotesis hubungan antara variabel independen dengan dependen, baik hubungan secara sendiri-sendiri (sederhana), maupun hubungan secara bersama-sama (ganda).

\section{A. Deskripsi Data}

\section{Prestasi akademik}

Dari data yang diperoleh di lapangan dirubah dalam bentuk T- Skor yang kemudian diolah secara statistik ke dalam daftar distribusi frekuensi, banyaknya kelas dihitung menurut aturan Sturges, diperoleh delapan kelas dengan nilai skor maksimum 77 dan skor minimum 30, sehingga rentang skor sebesar 47. Berdasarkan hasil perhitungan statistik deskriptif diperoleh bahwa data prestasi akademik mempunyai nilai rata-rata (mean) sebesar 50,01 dengan nilai standar deviasi 10,01 dimana nilai variansnya sebesar 100,2136 nilai median 49,28 dan nilai modus sebesar 50,50. Pengelompokan data dapat terlihat pada tabel distribusi frekuensi sebagai berikut.

Tabel 1. Distribusi Frekuensi Skor Variable $\mathrm{Y}$

\begin{tabular}{|c|c|c|c|c|c|c|}
\hline \multirow[b]{2}{*}{ No } & \multirow{2}{*}{$\begin{array}{c}\text { Kelas } \\
\text { Interval }\end{array}$} & \multicolumn{2}{|c|}{ Batas } & \multicolumn{3}{|c|}{ Frekuensi } \\
\hline & & Bwh & Ats & Abslt & Kmltf & Rltf \\
\hline 1 & $30-35$ & 29,5 & 35,5 & 5 & 5 & $4,24 \%$ \\
\hline 2 & $36-41$ & 35,5 & 41,5 & 24 & 29 & $20,34 \%$ \\
\hline 3 & $42-47$ & 41,5 & 47,5 & 22 & 51 & $18,64 \%$ \\
\hline 4 & $48-53$ & 47,5 & 53,5 & 27 & $\overline{78}$ & $22,8 \%$ \\
\hline 5 & $54-59$ & 53,5 & 59,5 & 22 & 100 & $18,64 \%$ \\
\hline 6 & $60-65$ & 59,5 & 65,5 & 8 & 108 & $6,78 \%$ \\
\hline 7 & $66-71$ & 65,5 & 71,5 & 5 & 11 & $4,24 \%$ \\
\hline 8 & 72-77 & 71,5 & 77,5 & 5 & 118 & $4,24 \%$ \\
\hline & & & & 118 & & $100 \%$ \\
\hline
\end{tabular}

Berdasarkan tabel di atas, selanjutnya dibuat histogramnya. Ada dua sumbu yang diperlukan dalam pembuatan histogram yakni sumbu vertikal sebagai sumbu frekuensi absolut, dan sumbu horizontal sebagai sumbu skor prestasi akademik. Dalam hal ini pada sumbu horizontal tertulis batas-batas kelas interval yaitu mulai dari 29,5 sampai 71,5. Harga-harga tersebut diperoleh dengan jalan mengurangkan angka 0,5 dari data terkecil dan menambahkan angka 0,5 setiap batas kelas pada batas tertinggi.

\section{Kesegaran Jasmani}

Data kesegaran jasmani mempunyai rentang skor empiris antara 67 sampai dengan 95, sehingga rentang skor sebesar 28. Hasil perhitungan data diperoleh rata-rata sebesar 77,14; simpangan baku sebesar 6,54; varians sebesar 42,7740; median sebesar 76,50; dan modus sebesar 75,83. 
Pengelompokan data dapat terlihat pada tabel distribusi frekuensi sebagai berikut.

Tabel 2. Distribusi Frekuensi Skor Variable $\mathrm{X}_{1}$

\begin{tabular}{|c|c|c|c|c|c|c|}
\hline \multirow{2}{*}{ No } & \multirow{2}{*}{$\begin{array}{c}\text { Kelas } \\
\text { Interval }\end{array}$} & \multicolumn{2}{|c|}{ Batas } & \multicolumn{3}{|c|}{ Frekuensi } \\
\hline & & Bwh & Ats & Abslt & Kmltf & RItf \\
\hline 1 & $67-70$ & 66,5 & 70,5 & 20 & 20 & $16,95 \%$ \\
\hline 2 & $71-74$ & 70,5 & 74,5 & 24 & 44 & 0,349 \\
\hline 3 & $75-78$ & 74,5 & 78,5 & 30 & 74 & $25,42 \%$ \\
\hline 4 & $79-82$ & 78,5 & 82,5 & 18 & 92 & $15,25 \%$ \\
\hline 5 & $83-86$ & 82,5 & 86,5 & 14 & 106 & $11,86 \%$ \\
\hline 6 & $87-90$ & 86,5 & 90,5 & 9 & 115 & $7,63 \%$ \\
\hline 7 & $91-94$ & 90,5 & 94,5 & 2 & 117 & $1,69 \%$ \\
\hline 8 & $95-98$ & 94,5 & 98,5 & 1 & 118 & $0,85 \%$ \\
\hline & & & & 118 & & $100 \%$ \\
\hline
\end{tabular}

\section{Disiplin}

Data disiplin mempunyai rentang skor teoretik antara 33 sampai 165 , dan rentang empiris antara 119 sampai dengan 150, sehingga rentang skor sebesar 31. Hasil perhitungan data diperoleh rata-rata sebesar 137,4; simpangan baku sebesar 6,61; varians sebesar 43,6979; median sebesar 137,67; dan modus sebesar 137,93. Pengelompokan data dapat terlihat pada tabel distribusi frekuensi sebagai berikut.

Tabel 3. Distribusi Frekuensi Skor Variabel $\mathrm{X}_{2}$

\begin{tabular}{|c|c|c|c|c|c|c|}
\hline \multirow[b]{2}{*}{ No } & \multirow{2}{*}{$\begin{array}{c}\text { Kelas } \\
\text { Interval }\end{array}$} & \multicolumn{2}{|c|}{ Batas } & \multicolumn{3}{|c|}{ Frekuensi } \\
\hline & & Bwh & Ats & Abslt & Kmltf & RItf \\
\hline 1 & $119-122$ & 118,5 & 122,5 & 2 & 2 & $1,69 \%$ \\
\hline 2 & $123-126$ & 5 &, 5 & 4 & 6 & $39 \%$ \\
\hline 3 & $127-130$ & 126,5 & 130,5 & 13 & 19 & $11,02 \%$ \\
\hline 4 & $131-134$ & 130,5 & 134,5 & 17 & 36 & $14,41 \%$ \\
\hline 5 & $135-138$ & 134,5 & 138,5 & 29 & 65 & $24,58 \%$ \\
\hline 6 & 139-142 & 138,5 & 142,5 & 27 & 92 & $22,88 \%$ \\
\hline 7 & $143-146$ & 142,5 & 146,5 & 19 & 111 & $16,10 \%$ \\
\hline 8 & $147-150$ & 146,5 & 150,5 & 7 & 118 & $5,93 \%$ \\
\hline & & & & 118 & & $100 \%$ \\
\hline
\end{tabular}

\section{Percaya Diri}

Data percaya diri mempunyai rentang skor teoretik antara 31 sampai 155 , dan rentang empiris antara 103 sampai dengan 142, sehingga rentang skor sebesar 39. Hasil perhitungan data diperoleh rata-rata sebesar 118,61; simpangan baku sebesar 7,55; varians sebesar 57,0604; median sebesar 117,23; dan modus sebesar 115,16. Pengelompokan data dapat terlihat pada tabel distribusi frekuensi sebagai berikut.

Tabel 4. Distribusi Frekuensi Skor Variabel $\mathrm{X}_{3}$

\begin{tabular}{|c|c|c|c|c|c|c|}
\hline \multirow{2}{*}{ No } & \multirow{2}{*}{$\begin{array}{c}\text { Kelas } \\
\text { Interval }\end{array}$} & \multicolumn{2}{|c|}{ Batas } & \multicolumn{3}{|c|}{ Frekuensi } \\
\hline & & Bwh & Ats & Abslt & Kmltf & Rltf \\
\hline 1 & $103-107$ & 102,5 & 107,5 & 4 & 4 & $3,39 \%$ \\
\hline 2 & $108-112$ & 107,5 & 112,5 & 20 & 24 & $16,95 \%$ \\
\hline 3 & $113-117$ & 112,5 & 117,5 & 37 & 61 & $31,36 \%$ \\
\hline 4 & $118-122$ & 117,5 & 122,5 & 22 & 83 & $18,64 \%$ \\
\hline 5 & $123-127$ & 122,5 & 127,5 & 19 & 102 & $16,10 \%$ \\
\hline 6 & $128-132$ & 127,5 & 132,5 & 11 & 113 & $9,32 \%$ \\
\hline 7 & $133-137$ & 132,5 & 137,5 & 4 & 117 & $3,39 \%$ \\
\hline 8 & $138-142$ & 137,5 & 142,5 & 1 & 118 & $0,85 \%$ \\
\hline & & & & 118 & & $100 \%$ \\
\hline
\end{tabular}

Hasil Perhitungan Statistik

\begin{tabular}{|l|c|c|c|c|}
\hline $\begin{array}{c}\text { Kete } \\
\text { rangan }\end{array}$ & $\begin{array}{c}\text { Variabel } \\
\mathbf{Y}\end{array}$ & $\begin{array}{c}\text { Variabel } \\
\mathbf{X 1}\end{array}$ & $\begin{array}{c}\text { Variab } \\
\mathbf{e l} \\
\mathbf{X 2}\end{array}$ & $\begin{array}{c}\text { Variabe } \\
\mathbf{I X 3}\end{array}$ \\
\hline Mean & 50,01 & 77,14 & 137,42 & 118,61 \\
\hline $\begin{array}{l}\text { Standard } \\
\text { Error }\end{array}$ & 0,92 & 0,60 & 0,61 & 0,70 \\
\hline Median & 49,28 & 76,50 & 137,67 & 117,23 \\
\hline Mode & 50,50 & 75,83 & 137,93 & 115,16 \\
\hline $\begin{array}{l}\text { Standard } \\
\text { Deviation }\end{array}$ & 10,01 & 6,54 & 6,61 & 7,55 \\
\hline $\begin{array}{l}\text { Sample } \\
\text { Variance }\end{array}$ & 100,2136 & 42,7740 & 43,6979 & 57,0604 \\
\hline Range & 47 & 28 & 31 & 39 \\
\hline Minimum & 30 & 67 & 119 & 103 \\
\hline Maximum & 77 & 95 & 150 & 142 \\
\hline Sum & 5901 & 9103 & 16215 & 13996 \\
\hline Count & 118 & 118 & 118 & 118 \\
\hline
\end{tabular}

Beberapa pembahasan dan interpretasi hasil penelitian di atas secara lebih 
mendalam dikemukakan pada uraian berikut:

\section{Hubungan kesegeran jasmani dengan prestasi akademik}

Hasil pengujian hipotesis pertama dapat disimpulkan bahwa terdapat hubungan positif antara kesegaran jasmani dengan prestasi akademik, dimana koefisien korelasi sebesar 0,641 menghasilkan thitung $=8,99$ lebih besar dari ttabel $=2,62$ pada $\alpha=0,01$. Kesimpulan tersebut menunjukkan bahwa semakin tinggi kesegaran jasmani, maka akan semakin tinggi pula prestasi akademik.

Korelasi antara kesegaran jasmani dengan prestasi akademik menunjukkan kebermaknaannya, baik melalui korelasi product moment maupun korelasi parsial. Hasil analisis ini memberikan petunjuk bahwa kesegaran jasmani merupakan salah satu faktor utama yang berkonstribusi terhadap prestasi akademik. Dari hasil itu pula dapat diinterpretasikan bahwa peningkatan kesegaran jasmani akan memberikan konstribusi yang berarti terhadap prestasi akademik.

\section{Hubungan disiplin dengan prestasi akademik}

Hasil pengujian hipotesis kedua dapat disimpulkan bahwa terdapat hubungan positif antara disiplin dengan prestasi akademik, dimana koefisien korelasi sebesar 0,631 menghasilkan thitung $=8,76$ lebih besar dari ttabel $=$ 2,62 pada $\alpha=0,01$. Kesimpulan tersebut menunjukkan bahwa semakin tinggi disiplin, maka akan semakin tinggi pula prestasi akademik.

Korelasi antara disiplin dengan prestasi akademik menunjukkan kebermaknaannya, baik melalui korelasi product moment maupun korelasi parsial. Hasil analisis ini memberikan petunjuk bahwa disiplin merupakan salah satu faktor utama yang berkonstribusi terhadap prestasi akademik. Dari hasil itu pula dapat diinterpretasikan bahwa peningkatan disiplin akan memberikan konstribusi yang berarti terhadap prestasi akademik.

\section{Hubungan percaya diri dengan prestasi akademik}

Hasil pengujian hipotesis ketiga dapat disimpulkan bahwa terdapat hubungan positif antara percaya diri dengan prestasi akademik, dimana koefisien korelasi sebesar 0,622 menghasilkan thitung $=8,56$ lebih besar dari ttabel $=2,62$ pada $\alpha=0,01$. Kesimpulan tersebut menunjukkan bahwa semakin tinggi percaya diri, maka akan semakin tinggi pula prestasi akademik.

Korelasi antara percaya diri dengan prestasi akademik menunjukkan kebermaknaannya, baik melalui korelasi product moment maupun korelasi parsial. Hasil analisis ini memberikan petunjuk bahwa percaya diri merupakan salah satu faktor utama yang berkonstribusi terhadap prestasi akademik. Dari hasil itu pula dapat diinterpretasikan bahwa peningkatan percaya diri akan memberikan konstribusi yang berarti terhadap prestasi akademik.

\section{Hubungan antara kesegaran} jasmani, disiplin, dan percaya diri secara Bersama-sama dengan prestasi akademik

Hasil pengujian hipotesis keempat dapat disimpulkan bahwa kesegaran jasmani, disiplin, dan percaya diri secara bersama-sama mempunyai hubungan positif dengan prestasi akademik. Koefisien korelasi ganda antara ketiga 
variabel bebas dengan variabel terikat Ry.123 sebesar 0,814 menghasilkan Fhitung $=74,61$ lebih besar dari Ftabel $=$ 3,96 pada $\alpha=0,01$.

Dari koefisien korelasi tersebut, dapat dihitung koefisien determinasi (Ry.123) sebesar 0,6626 berarti bahwa $66,26 \%$ proporsi varians prestasi akademik dapat dijelaskan secara bersama-sama oleh kesegaran jasmani, disiplin, serta percaya diri.

\section{KESIMPULAN}

Berdasarkan Hasil penelitian dapat disimpulkan bahwa Sesuai dengan tujuan penelitian, yaitu ingin mengetahui hubungan antara Kesegaran Jasmani, Disiplin dan Percaya Diri dengan Prestasi Akademik Taruna, baik secara sendiri-sendiri maupun bersama-sama, berdasarkan hasil pengolahan dan analisis data, serta pengujian hipotesis, dapat disimpulkan bahwa:

Pertama, terdapat hubungan yang positif antara Kesegaran Jasmani dengan Prestasi Akademik Taruna. Hal ini berarti bahwa semakin baik kesegaran jasmani taruna maka makin baik pula prestasi akademik taruna. Begitu pula sebaliknya makin rendah kesegaran jasmani maka makin rendah pula prestasi akademik. Oleh karena itu kesegaran jasmani merupakan salah satu variable yang perlu mendapatkan perhatian di dalam meningkatkan prestasi akademik Taruna Sekolah Tinggi Transportasi Darat.

Kedua, terdapat hubungan yang positif disiplin dengan prestasi akademik taruna Sekolah Tinggi Transportasi darat. Hal ini berarti bahwa semakin baik disiplin seorang taruna maka semakin baik pula prestasi akademik taruna. Begitu pula sebaliknya makin rendah disiplin maka makin rendah pula nilai akademik. Oleh karena itu disiplin taruna merupakan salah satu variable yang perlu mendapat perhatian di dalam meningkatkan prestasi akademik taruna Sekolah Tinggi Transportasi Darat.

Ketiga, antara Percaya Diri dengan prestasi akademik terdapat hubungan positif. Hal ini berarti bahwa semakin baik Percaya diri seorang taruna maka semakin baik pula prestasi akademik taruna. Begitu pula sebaliknya makin rendah percaya diri taruna maka makin rendah pula nilai akademik taruna. Oleh karena itu percaya diri taruna merupakan salah satu variable yang perlu mendapat perhatian di dalam meningkatkan prestasi akademik Taruna Sekolah Tinggi Transportasi Darat.

Ke-empat, secara bersama-sama terdapat hubungan positif antara Kesegaran Jasmani, Disiplin dan Percaya Diri dengan Prestasi Akademik Taruna. Hal ini berarti bahwa semakin baik kesegaran jasmani, disiplin dan percaya diri taruna secara bersama-sama maka semakin baik pula prestasi akademik taruna. Begitu pula sebaliknya makin rendah kesegaran jasmani, disiplin dan percaya diri taruna secara bersama-sama maka makin rendah pula nilai akademik. Oleh karena itu kesegaran jasmani, disiplin dan percaya diri taruna secara bersama-sama taruna merupakan tiga variable yang perlu mendapat perhatian di dalam meningkatkan prestasi akademik taruna Sekolah Tinggi Transportasi Darat.

Hasil penelitian menyimpulkan bahwa Kesegaran Jasmani, Disiplin dan Percaya Diri taruna memiliki hubungan yang cukup erat dengan Prestasi Akademik Taruna. Makin tinggi atau makin baik Kesegaran Jasmani, Disiplin dan Percaya Diri taruna, maka makin tinggi atau makin baik pula Prestasi Akademik Taruna. 
Prestasi akademik sangat menentukan keberhasilan taruna dalam pembelajaran dan dapat instruksi yang diberikan. Disiplin dan tanggung jawab merupakan wujud dari cerminan diri seorang taruna akan tugas dan tanggung jawab yang diembankannya. Wujud terrsebut dalam bentuk mengerjakan sebaik-baiknya tugas yang merupakan tanggung jawabnya dan berusaha tidak mengingkari setiap janji mengikuti kelas dan tidak mangkir.

Taruna merupakan pribadi dinamis yang dapat bekerjasama dan bergaul dengan orang banyak, selalu ramah, sabar, memiliki kestabilan emosi, dan mempunyai sifat penolong. Memelihara hubungan yang baik dengan para pendidik dan memelihara hubungan dengan seluruh pihak yang berkaitan dengan tenaga kependidikan. Usaha tersebut berupa interaksi yang harmonis dan jalinan kerjasama yang baik, sehingga ia akan diterima dengan baik ditengah-tengah meraka.

Taruna yang selalu berusaha menjadi panutan, yang terbuka menerima kritikan yang sifatnya membangun untuk kemajuan ia, dan selalu menjaga kestabilan emosi disetiap kesempatan dan situasi walaupun dalam situasi yang tidak memungkinkan.

\section{DAFTAR PUSTAKA}

A.M, Sardiman. 2014. Interaksi Dan Motivasi Belajar Mengajar. Jakarta: Rajawali Pers,

Arikunto, Suharsimi. 2006. Prosedur Penelitian (Suatu PendekatanPraktek), Jakarta: PT Rineka Cipta

Castelli. Darla M., 2015. Active Education: Growing Evidence on Physical Activity and Academic Performance. Austin: The University of Texas.
Djaali, Pudji Mujiono. 2008. Pengukuran dalam bidang Pendidikan. Jakarta: Grasindo.

Djamarah, Syaiful Bahri. 2006. Strategi Belajar Mengajar. Jakarta: PT Rineka Cipta.

Hadi, Pranata, 2016 Fisiologi Latihan. Yogyakarta: Universitas Negeri Yogyakarta.

Hakim, Thursan, 2002. Mengatasi Rasa Tidak Percaya Diri. Jakarta: Purwa Suara.

Hamiyah Nur \& Jauhar Mohammad. 2014. Strategi Belajar Mengajar Di Kelas. Jakarta: Prestasi Pustakarya.

Hamruni. 2011. Strategi Pembelajaran. Yogyakarta: Insan Madani.

Hillman. Charles h. 2005. Aerobic Fitness and Neurocognitive Function in Healthy Preadolescent Children. Illinois: University of Illinois.

Husdarta H.J.S. 2010. Psikologi Olahraga. Bandung: Alfabeta.

Iyan AR. 2014. Buku Pintar Tampil Percaya Diri. Yogyakarta: Araska.

Jichun, Jin. 2000. Facing The 21ST Century And Bringing up HighQuality Sport Talented Personnel. Beijing: Third Asia-Pacifik Conggres of Sport and Physical Education University Presidents.

Komarudin. 2013. Psikologi Olahraga. Bandung: PT. Remaja Rosdakarya.

Nasrudin, Acep, 2015. Disiplin dalam pandangan Islam. Bandung: Scrib.

NBTA, 2010. Discipline and Classroom Management. Canada: Department of Education.

Tangkudung, James dan Wahyuningtyas. 2012. Kepelatihan Olahraga Jakarta: Cerdas Jaya.

Tangkudung, James. 2012. Kepelatihan Olahraga. Jakarta: Cerdas Jaya.

Widiastuti. 2011. Tes dan Pengukuran Olahraga. Jakarta: Bumi Timur Jaya 